\title{
Editorial: Philosophy and Public Impact
}

In a time when governments are seeking to rein back public expenditure, those receiving government funding can expect to be called to account. In Britain (excluding Scotland) block funding for teaching in universities in the arts and social sciences is to be replaced by students having (eventually) to pay fees for it themselves, which may concentrate minds somewhat. With research it is a rather different matter. There will still be government research councils (even in Scotland), but the assessment of the potential 'economic and societal impact' of the research is now a major element in the making of funding decisions.

Academics applying for research grants will henceforth have to include in their submissions a statement about 'the demonstrable contribution' that their work will make to 'society and the economy'. They 'will need to consider the wider potential of your research in relation to industry, the public sector, government policy, the third sector, the general public and the wider user base'.

How might philosophy fare in this context? Are its contributions demonstrable (whatever that means)? An immediate, and perhaps in the end the correct, reaction is to insist that, broadly considered, any serious philosophical reflections on the world, the soul and God are likely in unsuspected and sometimes profound ways to have 'economic and societal impact'. That this would not cut much ice with people who use phrases like 'the wider user base' does not mean that it is not the correct and only valid response.

It would be tempting at this point to go beyond the purist response that, one way or another, even the most apparently abstruse philosophical reflections may eventually enter and affect public consciousness (and in the past often have done so). We could play the bureaucratic game and start talking about the more direct contribution philosophers have made and continue to make as 'public intellectuals', both in Britain and abroad, affecting public policy and the climate of pubic debate generally.

Historically, however, the record of philosophers as 'public intellectuals' has not been a happy one, as a quick survey of the history of philosophy might show, from the days of Plato and Aristotle in antiquity to at least some of the public interventions of the likes of Heidegger, Sartre and Russell nearer to our own time. For whatever 


\section{Editorial}

reason, historically there seems to have been no clear correlation between philosophic wisdom and practical wisdom, nor does philosophy in itself afford any reliable credentials for entry into public debate.

Philosophers, being articulate and argumentative by training, and often having time on their hands as well, will often involve themselves in public affairs. Indeed, despite denials of the fact from some quarters, philosophers as a group punch well above their weight in getting themselves heard in the public square. The results, though, are mixed, as we have seen, and, for all the good that some do, continue to see. Perhaps part of the reason for this is that philosophy as a subject has no party line, so to speak: philosophers speaking ex cathedra will support causes of all sorts, and will use their professionally acquired forensic abilities to do so, whether the cause in question is a good one, a bad one, or even a silly one. Before rushing to defend philosophy in terms of its direct public impact, we need to remind ourselves that it is not for their interventions in public life that great or even good philosophers have primarily been admired, but for the quality of their serious philosophy.

We should be wary of falling into the trap of defending philosophy's 'impact' in terms of the noise philosophers make in public debate or as advisors to governments or other corporations and agencies. It will do philosophy no good, as audiences come to realise that philosophers as a group have no superior or special talent for that sort of thing; nor, if philosophers are side-tracked by the demands of politicians and research councils into pursuing that sort of fame, will it be conducive to good philosophy. 